\title{
ANALISIS PENGARUH KUALITAS PELAYANAN TERHADAP KEPUASAN PRAJA DALAM MENGGUNAKAN PERPUSTAKAAN INSTITUT PEMERINTAH DALAM NEGERI DI JATINANGOR
}

\author{
Eti Sumiati \\ Perpustakaan IPDN Jatinangor Kabupaten Sumedang \\ E-mail: Esumiati70@gmail.com
}

\begin{abstract}
ABSTRAK
Pendidikan memiliki peranan penting untuk kemajuan penerus bangsa, termasuk di Indonesia. Perpustakaan merupakan unsur penting dan tidak mungkin dihilangkan dalam sistem pendidikan. Keinginan yang kuat untuk mewujudkan sebuah perpustakaan yang ideal merupakan kepuasan tersendiri bagi pustakawan. Kepuasan yang dirasakan praja di lingkungan Institut Pemerintah Dalam Negeri Jatinangor adalah menjadi fokus utama pustakawan beserta petugas perpustakaan sebagai titik acuan keberhasilan pemanfaatan perpustakaan. Pentingnya peran bagi pustakawan dan petugas layanan perpustakaan agar dapat bersaing dan merangkul media internet sebagai fasilitas layanan yang dapat disediakan perpustakaan. Berdasarkan hasil observasi, sebagian besar praja di lingkungan Institut Pemerintah Dalam Negeri mengatakan sarana komputer yang disediakan kurang, komputer dengan bandwidth kecil dan kurangnya katalog penelusuran koleksi buku di lingkungan Institut Pemerintah Dalam Negeri Jatinangor. Dalam penelitian ini penulis menggunakan metode deskriptif. Dan data yang dibutuhkan dalam melakukan penelitian ini adalah data primer dan data sekunder. Sumber data penelitian ini bersumber dari informan dan literatur. Kualitas pelayanan sangat berhubungan dengan kepuasan pelanggan yaitu pemustaka. Dalam hal ini penulis menerapkan dimensi-dimensi kualitas pelayanan yaitu tangible, reliability, responsiveness, assurance dan empathy sebagai faktor yang diduga mampu menumbuhkan kepuasan pemustaka. Hasil analisis menunjukkan bahwa dimensi-dimensi kualitas pelayanan berpengaruh terhadap kepuasan praja sebagai pemustaka perpustakaan Institut Pemerintah Dalam Negeri di Jatinangor. Dimana yang sangat berpengaruh adalah fasilitas yang disediakan perpustakaan sedangkan pelayanan petugas secara masing-masing individu merupakan faktor pendukung dalam jalannya administrasi perpustakaan Institut Pemerintah Dalam Negeri di Jatinangor. Hal ini selaras dengan hasil penelitian oleh Rusdi (2017) yang menyimpulkan bahwa kualitas pelayanan perpustakaan berpengaruh terhadap kepuasan pemustaka.
\end{abstract}

Kata kunci: Kualitas Pelayanan, Kepuasan Pemustaka

\section{PENDAHULUAN}

\section{Latar Belakang}

Pendidikan memiliki peranan yang penting dalam memajukan suatu bangsa, termasuk di Indonesia. Global Talent Competitiveness Index atau disingkat GTCI adalah salah satu alat untuk mengukur tingkat daya saing negara berdasarkan kemampuan sumber daya manusia yang dimiliki oleh suatu negara tersebut. Indikator penilaian dalam sistem ini salah satunya adalah pendidikan. Berdasarkan data Global Talent Competitiveness Index yang dipublikasikan pada tahun 2019 di ASEAN, ranking pertama yang paling baik adalah negara Singapura dengan skor sebesar 77,27. Sedangkan Indonesia termasuk dalam ranking ke enam dengan skor sebesar 38,61. Menurut publikasi yang disampaikan Global Talent Competitiveness Index "beberapa unsur pendidikan yang menjadi ukuran diantaranya pendidikan formal, literasi baca-tulis-hitung, jurnal ilmiah, mahasiswa internasional, relevansi pendidikan dengan dunia bisnis, jumlah lulusan teknisi dan peneliti, jumlah hasil riset, dan jurnal ilmiah".

Dalam hal ini perpustakaan berperan penting dan sangat berkaitan dalam sistem pendidikan. Perpustakaan 
berkaitan erat dengan literasi baca, jurnal ilmiah dan hasil riset. Keinginan yang kuat untuk mewujudkan sebuah perpustakaan yang ideal merupakan kepuasan tersendiri bagi pustakawan. Hal itu berarti tujuannya harus mengarah pada penetapan standar kualifikasi pusat sumber belajar. Standar kualifikasi pun bertujuan memenuhi kepuasan pemustaka yaitu kepuasan dalam mencari informasi secara lengkap, cepat dan tepat.

Pasal 4 Undang-undang Republik Indonesia No. 43 Tahun 2007 menyebutkan bahwa "perpustakaan memiliki tujuan memberikan layanan kepada pemustaka, meningkatkan kegemaran membaca, serta memperluas wawasan dan pengetahuan untuk mencerdaskan kehidupan bangsa". Dalam pasal 3 Undang-undang Republik Indonesia No.43 tahun 2007 disebutkan bahwa "perpustakaan berfungsi sebagai wahana pendidikan, penelitian, pelestarian, informasi, dan rekreasi untuk meningkatkan kecerdasan dan keberdayaan bangsa". Jenis-jenis perpustakaan berdasarkan Undang-undang Republik Indonesia No.43 Tahun 2007 Pasal 20 yaitu: "perpustakaan terdiri atas Perpustakaan Nasional, Perpustakaan Umum. Perpustakaan Sekolah/Madrasah, Perpustakaan Perguruan Tinggi dan Perpustakaan Khusus".

Perpustakaan Institut Pemerintah Dalam Negeri merupakan perpustakaan tingkat perguruan tinggi, dimana sebagian besar pemustaka adalah praja di kampus tersebut. Menurut Sulistyo-Basuki (2004:101) menyatakan bahwa:

"Perpustakaan perguruan tinggi ialah
perpustakaan yang ada di lingkungan perguruan
tinggi (universitas, institut, sekolah tinggi,
politeknik, fakultas, jurusan). Sebagai bagian dari
Tri Dharma perguruan tinggi, maka perguruan
tinggi melakukan penelitian yang hasilnya
disimpan di perpustakaan perguruan tinggi."

Menurut Hasugian (2009: 80) mengatakan bahwa tujuan perpustakaan perguruan tinggi di Indonesia yaitu menyampaikan layanan informasi untuk kegiatan belajar, penelitian, dan pengabdian kepada masyarakat dalam rangka melaksanakan Tri Dharma Perguruan Tinggi”. Menurut SNP 10 Tahun 2011 menuliskan bahwa perpustakaan perguruan tinggi adalah perpustakaan yang bertujuan memenuhi kebutuhan informasi pengajar dan mahasiswa di perguruan tinggi.

Pustakawan dan petugas perpustakaan Institut Pemerintah Dalam Negeri memiliki tujuan mendasar yaitu memberikan pelayanan yang terbaik untuk praja dalam melakukan pendidikan formal di wilayah Institut pendidikan. Menurut Puji Hastuti (2012) menyatakan bahwa ada beberapa pelayanan yang dilakukan di perpustakaan antara lain: layanan sirkulasi, layanan referens, layanan penyebaran informasi terbaru, layanan penerjemahan, layanan fotokopi.

Pendapat menurut Arifin dan Rahayu (2011), kepuasaan merupakan keadaan yang dirasakan seseorang yang merupakan hasil dari membandingkan produk yang dirasakan dalam hubungannya dengan harapan seseorang. Sedangkan pendapat lain menurut Asmuji (2012) mengatakan kepuasan adalah perasaan senang atau kecewa seseorang yang muncul setelah membandingkan antara persepsi/kesannya terhadap kinerja (atau hasil) suatu produk dan harapan-harapannya. Dalam hal ini kepuasan yang dirasakan praja di lingkungan Institut Pemerintah Dalam Negeri Jatinangor adalah menjadi fokus utama pustakawan beserta petugas perpustakaan sebagai titik acuan keberhasilan pemanfaatan perpustakaan.

Namun dengan berkembangnya media sosial yang memudahkan dalam mendapatkan informasi serta akses internet yang begitu mudah didapat. Perpustakaan dapat diistilahkan memiliki pesaing dalam memenuhi kepuasan pemustaka. Banyak yang beranggapan lebih baik menggunakan media internet dibandingkan harus berkunjung ke perpustakaan untuk mencari informasi karena hal tersebut lebih praktis. Akan tetapi media sosial juga dapat menjadi keuntungan bagi perpustakaan dalam mengembangkan dan menarik minat pembaca di perpustakaan.

Pentingnya peran bagi pustakawan dan petugas layanan perpustakaan agar dapat bersaing dan merangkul media internet sebagai fasilitas layanan yang dapat disediakan perpustakaan. Berdasarkan hasil observasi, sebagian besar praja di lingkungan Institut Pemerintah Dalam Negeri mengatakan sarana komputer yang disediakan kurang, komputer dengan bandwidth kecil dan kurangnya katalog penelusuran koleksi buku di lingkungan Institut Pemerintah Dalam Negeri Jatinangor.

Sehubungan dengan permasalahan yang dihadapi petugas dan pustakawan di Institut Pemerintah Dalam Negeri Jatinangor, penulis akan menganalisis mengenai pengaruh kualitas pelayanan terhadap kepuasan praja di Institut Pemerintah Dalam Negeri Jatinangor.

\section{Tujuan}

Penelitian ini bertujuan untuk mengetahui mengenai seberapa besar kualitas pelayanan yang diberikan petugas perpustakaan dan pustakawan terhadap kepuasaan yang dirasakan oleh praja dalam menggunakan fasilitas di 
Perpustakaan Institut Pemerintah Dalam Negeri di Jatinangor.

\section{LANDASAN TEORI}

\section{Perpustakaan}

Perpustakaan memiliki asal kata yaitu pustaka yang memiliki arti buku. Perpustakaan merupakan suatu sarana yang menyediakan buku-buku, jurnal tulis dan sarana belajar lainnya yang terintegrasi dalam suatu lingkungan tertentu. Arti perpustakaan menurut Undang-Undang No. 43 Tahun 2007 pasal 1 ayat 1 mengemukakan bahwa:

"Institusi pengelola koleksi karya tulis, karya cetak, dan/atau karya reka secara profesional dengan sistem yang baku guna memenuhi kebutuhan pendidikan, penelitian, pelestarian, informasi, dan rekreasi bagi para pemustaka."

Menurut Sulistyo Basuki oleh Febriyani (2013:1) menyatakan bahwa perpustakaan merupakan sebuah ruangan dan bagian gedung ataupun keseluruhan gedung yang digunakan untuk menyimpan buku dan terbitan lainnya yang disimpan menurut tata susunan tertentu untuk dapat digunakan oleh pembaca dan tidak untuk diperdagangkan. Trima dalam Sinaga (2005:220) menyatakan pengertian perpustakaan adalah sekumpulan bahan pustaka, baik yang tercetak maupun rekaman lainnya yang pada suatu tempat tertentu telah diatur sedemikian rupa untuk mempermudah pemustaka dalam permasalahan ini adalah praja, dalam mencari informasi yang diperlukan. Dan tujuan utama sebenarnya perpustakaan adalah melayani kebutuhan informasi masyarakat bukan untuk diperjualbelikan.

Pada Undang-Undang RI No. 43 Tahun 2007 menyebutkan bahwa perpustakaan bertujuan memberikan layanan kepada pemustaka, meningkatkan kegemaran membaca, serta memperluas wawasan dan pengetahuan untuk mencerdaskan kehidupan bangsa. Begitu pula disebutkan bahwa fungsi perpustakaan adalah sebagai wahana pendidikan, penelitian, pelestarian, informasi, dan rekreasi untuk meningkatkan kecerdasan dan keberdayaan bangsa.

Sutarno NS (2006:37) memaparkan jenis perpustakaan berbeda-beda diantaranya yaitu perpustakaan Nasional RI, Badan perpustakaan Daerah, perpustakaan umum, perpustakaan perguruan tinggi, perpustakaan sekolah, perpustakaan khusus, perpustakaan lembaga Keagamaan, perpustakaan Internasional, perpustakaan kantor perwakilan Negara Asing, perpustakaan pribadi atau milik keluarga, dan perpustakaan digital. Dalam penelitian ini penulis menganalisis perpustakaan perguruan tinggi yaitu Perpustakaan Institut Pemerintah Dalam Negeri di Jatinangor.

\section{Perpustakaan Perguruan Tinggi}

Menurut Sulistyo-Basuki (2004:101) menyatakan bahwa:
"Perpustakaan perguruan tinggi ialah perpustakaan yang ada di lingkungan perguruan tinggi (universitas, institut, sekolah tinggi, politeknik, fakultas, jurusan). Sebagai bagian dari Tri Dharma perguruan tinggi, maka perguruan tinggi melakukan penelitian yang hasilnya disimpan di perpustakaan perguruan tinggi."

Tujuan perpustakaan perguruan tinggi di Indonesia dalam pemaparan Hasugian (2009: 80) menyatakan bahwa" tujuannya adalah memberikan layanan informasi untuk kegiatan belajar, penelitian, dan pengabdian kepada masyarakat dalam rangka melaksanakan Tri Dharma Perguruan Tinggi”.

Fungsi perpustakaan perguruan tinggi dalam pelaksanaan Undang-Undang No. 43 Tahun 2007 adalah:

1. Fungsi sebagai sumber belajar,

Sebagai salah satu pusat sumber belajar perpustakaan perguruan tinggi harus dilengkapi oleh koleksi bahan perpustakaan.

2. Fungsi sebagai sumber penelitian, Sebagai sumber informasi untuk penelitian dan sebagai tempat penelitian itu sendiri. Sebagaimana kita ketahui bahwa salah satu dharma dari tri dharma perguruan tinggi adalah penelitian.

3. Fungsi sebagai pusat deposit internal perguruan tinggi,

4. Fungsi sebagai pusat pelestarian informasi, dan

5. Fungsi sebagai pusat jejaring bagi civitas-akademika di lingkungan perguruan tinggi.

\section{Kualitas Layanan}

Dikemukakan oleh Kotler (2012:49) bahwa "kualitas adalah keseluruhan ciri serta sifat dari suatu produk atau pelayanan yang berpengaruh pada kemampuannya untuk memuaskan kebutuhan yang dinyatakan atau tersirat". Sedangkan menurut Kotler dalam Laksana (2008:85) yaitu

"A Service any act or performance that one party can offer to other that is essentially intangible and does not result in the Ownership of anything, 
its production may or may no be to a physical product".

Yang dimaksud bahwa pelayanan adalah tindakantindakan dengan kata lain kegiatan yang dapat ditawarkan oleh satu pihak kepada pihak lain, yang pada dasarnya tidak berwujud atau tidak dihubungkan oleh bentuk fisik suatu produk.

Dimensi kualitas pelayanan menurut Lupiyadi (2006:18 2) menyatakan terdapat lima dimensi diantaranya yaitu:

1. Tangible atau bukti fisik

Yaitu unsur-unsur fasilitas fisik, perlengkapan dan sarana dan prasarana yang disediakan serta komponen-komponen utama kualitas pelayanan. Kemampuan dalam organisasi untuk menunjukkan eksistensinya kepada pihak eksternal. Penampilan dan kemampuan sarana dan prasarana fisik organisasi dan keadaan lingkungan sekitarnya adalah bukti nyata dari pelayanan yang diberikan oleh pemberi jasa.

2. Reliability atau keandalan

Yaitu berhubungan dengan suatu institusi yang mampu memberikan pelayanan secara spesifik dan dapat dipercayai. Kemampuan untuk memberikan layanan tepat sasaran yang terjamin kepercayaannya. Kinerja sepatutnya disesuaikan dengan kebutuhan pelanggan, seperti ketepatan waktu, mendapatkan pelayanan yang sama untuk semua pelanggan tanpa kesalahan, dan rasa atau memiliki sikap simpatik.

3. Responsiveness atau daya tanggap

Yaitu memiliki rasa ingin membantu dan menanggapi permintaan secara tepat dan cepat. Keinginan untuk memberikan pelayanan secepat mungkin kepada pelanggan dengan memberikan informasi yang jelas. Dan tidak membiarkan pelanggan menunggu tanpa adanya alasan yang membuat persepsi buruk terhadap kualitas layanan.

4. Assurance atau jaminan

Diantaranya adalah memiliki sikap sopan santun karyawan terhadap pelanggan, keamanan dan memiliki pengetahuan dalam diri pegawai yang dapat dipercaya oleh pelanggan. Dimana jaminan ini terdiri dari beberapa faktor yaitu komunikasi, kredibilitas, keamanan, kompetensi dan sopan santun.

5. Emphaty atau empati

Yaitu mengenai keadaan karyawan yang mampu memahami kebutuhan pelanggan dan dapat menghadapi keluhan pelanggan. Memberikan perhatian yang bersifat pribadi diberikan kepada para pelanggan dengan memahami kebutuhan pelanggan.
Suatu institusi diharapkan memiliki pengertian dan memahami tentang pelanggan beserta kebutuhannya secara fisik dan spesifik, dan serta memiliki waktu pengoperasian yang nyaman bagi pelanggan.

Ada beberapa ahli yang meneliti mengenai beberapa jenis jasa dan identifikasi masalah menghasilkan sepuluh unsur yang menentukan jasa dikutip dalam Parasuraman (1925), yaitu meliputi:

1. Reliability

Meliputi dua hal yaitu konsistensi kerja dan kemampuan agar dapat dipercaya. Perusahaan yang berhubungan harus memenuhi janjinya sesuai dengan apa yang sudah disepakati.

2. Responsiveness

Yaitu keinginan dan kesiapan para karyawan untuk memberikan jasa yang dibutuhkan pelanggan.

3. Competence

Setiap orang dalam suatu perusahaan memiliki keahlian, keterampilan dan pengetahuan yang dibutuhkan agar dapat memberikan jasa tertentu.

4. Access

Meliputi kemudahan untuk dihubungi dan ditemui. Maka dari itu, fasilitas yang disediakan haruslah pada posisi yang strategis, mudah dijangkau, gampang untuk memproses, dan lainnya.

5. Courtesy

Meliputi sikap sopan santun, respect, perhatian, dan keramahan yang dimiliki para personal.

6. Communication

Yaitu memberikan informasi dengan cara penyampaian yang mudah dipahami serta mau mendengarkan saran dan keluhan pelanggan.

7. Credibility

Meliputi sifat jujur dan dapat dipercaya. Kredibilitas yang mencakup nama perusahaan, reputasi perusahaan, karakteristik pribadi atau personal, dan interaksi dengan pelanggan.

8. Security

Yaitu aman dari bahaya, resiko, atau keragu-raguan.

9. Aspek

Aspek ini meliputi keamanan secara fisik (physical safety), keamanan finansial (physical safety), keamanan finansial (financial safety), dan kerahasiaan (confidentiality).

Understanding/Knowing the customer, yaitu usaha untuk memahami kebutuhan pelanggan.

10. Tangibles

Yaitu bukti fisik dari jasa, bisa berupa fasilitas fisik, peralatan yang digunakan, representasi fisik dari jasa (misalnya kartu kredit plastik). 
Dalam perkembangan selanjutnya, Parasuraman (1988) menemukan bahwa sepuluh dimensi yang ada dapat dirangkum menjadi hanya lima dimensi pokok. Kelima dimensi pokok tersebut meliputi:

1. Bukti langsung (tangibles)

2. Keandalan

3. Daya tanggap (responsiveness)

4. Jaminan (assurance) dan

5. Empati

\section{Kepuasan Pemustaka}

Menurut Kotler \& Keller (2013:194) mengatakan bahwa "kepuasan pelanggan adalah tingkat keadaan perasaan seseorang yang merupakan hasil perbandingan antara penilaian kinerja/hasil akhir produk dalam hubungannya dengan harapan pelanggan". Kepuasaan adalah level kondisi yang dirasakan seseorang dengan membandingkan apa yang dirasakan dalam hubungannya dengan harapan seseorang (Arifin dan Rahayu, 2011). Sedangkan pendapat lain menurut Asmuji (2012) mengatakan bahwa kepuasan adalah perasaan senang atau kecewa seseorang yang muncul setelah membandingkan antara persepsi/kesannya terhadap kinerja (atau hasil) suatu produk dan harapan-harapannya.

Kepuasan merupakan hasil analisa perbandingan terhadap suatu produk yang terlihat maupun jasa yang dirasakan pada kesesuaian dengan harapan. Menurut Sulistyo Basuki (1992:204) adanya kepuasan pemustaka akan timbul karena terdapat beberapa faktor yang salah satunya yaitu kecepatan pemberian layanan informasi. Berdasarkan hal itu, kepuasan pemustaka merupakan suatu perbandingan antara kinerja yang diterimanya yaitu suatu layanan dengan persepsi atau kesesuaian dengan harapan pemustaka, dimana setiap penyedia jasa seperti perpustakaan harus memahami nilai-nilai yang diharapkan oleh pemustaka dan berusaha memenuhi harapan tersebut dengan sebaik mungkin.

\section{Profile Perpustakaan}

Perpustakaan Institut Pemerintah Dalam Negeri sebagaimana perpustakaan di Perguruan Tinggi lain juga harus dapat berfungsi sebagai "Jantung Perguruan Tinggi”. Untuk itu, perpustakaan harus selalu memberikan layanan yang kontributif terhadap aktivitas belajar mengajar, antara lain updating buku, jurnal, karya ilmiah, seri pengetahuan dalam bentuk DVD, e-book, novel serta koleksi dan penyediaan fasilitas lainnya. Diharapkan mahasiswa/praja Institut Pemerintah Dalam
Negeri dapat menghabiskan sebagian waktunya untuk membaca buku, mengerjakan tugas sekaligus refreshing dengan memanfaatkan fasilitas yang ada.

Pada tahun 2004 perpustakaan Institut Pemerintah Dalam Negeri mendapat sumbangan dari World Bank berupa fasilitas seperti komputer dan peralatan teknologi dan informasi. Pada tahun 2005, perpustakaan Institut Pemerintah Dalam Negeri berubah statusnya sebagai e-library. Dengan e-library tersebut, pengguna perpustakaan dapat mencari buku dan sumber-sumber informasi yang diinginkan menggunakan penelusuran katalog online, mengunduh artikel/karya ilmiah, jurnal internasional secara gratis, membaca karya ilmiah secara online, dan lain-lain.

Dimasa yang akan datang, koleksi dan fasilitas perpustakaan Institut Pemerintah Dalam Negeri akan senantiasa diperbaharui baik koleksi buku-buku, fasilitas IT, layanan sesuai dengan tuntutan kebutuhan dan perkembangan teknologi.

\section{Visi Perpustakaan Institut Pemerintah Dalam Negeri}

Menjadi pusat pengelola dan penyebaran informasi yang berbasis teknologi informasi guna mendukung pelaksanaan pengajaran, penelitian, dan pengabdian masyarakat serta pengembangan ilmu dan terapan pemerintahan.

\section{Misi Perpustakaan Institut Pemerintah Dalam Negeri}

1. Meningkatkan kemampuan mengelola dan meyebarkan informasi guna mendukung kebutuhan informasi bagi sivitas akademika di Institut Pemerintah Dalam Negeri.

2. Meningkatkan kemampuan mengelola dan menyebarkan informasi atas kekayaan ilmiah yang dimiliki oleh Institut Pemerintah Dalam Negeri.

3. Menunjang sistem jaringan informasi baik di antara perpustakaan perguruan tinggi atau perpustakaan lain di tingkat regional, nasional, dan internasional.

4. Mengelola dan menyebarkan informasi tentang perkembangan ilmu pemerintahan dan penerapannya khususnya di lingkungan pemerintahan daerah dan pemerintah pusat.

\section{Tujuan}

1. Menyediakan dan mengupayakan ketersediaan akses informasi yang mendukung proses belajar-mengajar, penelitian, dan pengabdian masyarakat dengan memanfaatkan kemampuan teknologi informasi. 
2. Mendokumentasikan dan menyebarluaskan hasil sivitas akademika dengan memanfaatkan kemampuan teknologi informasi.

3. Mengupayakan terwujudnya jaringan informasi di lingkungan perpustakaan perguruan tinggi Institut Pemerintah Dalam Negeri atau perpustakaan lain di tingkat regional, nasional, maupun internasional.

4. Mendokumentasikan dan menyebarluaskan informasi tentang perkembangan ilmu pemerintahan dan penerapannya dengan memanfaatkan kemampuan teknologi informasi.

\section{Fungsi}

1. Sebagai sumber media informasi dan layanan program pendidikan dan pengajaran;

2. Sebagai sumber media informasi dan layanan program penelitian;

3. Sebagai sumber media informasi dan layanan program pengabdian pada masyarakat;

4. Sebagai media rekreasi alternatif bagi sivitas akademika perguruan tinggi.

\section{Jenis-jenis Layanan}

\section{Sirkulasi}

Melayani peminjaman, perpanjangan, dan pengembalian buku dan koleksi lainnya. Khusus koleksi referensi, Laporan Akhir, skripsi, tesis, karya tulis penelitian, naskah publikasi, CD/DVD dan multimedia, serta buku/jurnal/majalah yang berlabel $\mathrm{C}$ (cadangan) tidak dipinjamkan.

2. Keanggotaan Melayani pendaftaran anggota serta perpanjangan kartu keanggotaan.

3. Multimedia

Perpustakaan melayani pengguna yang hendak memanfaatkan koleksi e-book, tutorial, dan seri pengetahuan dalam bentuk CD/DVD.

4. Internet

Perpustakaan melayani pengguna yang hendak memanfaatkan fasilitas internet dan hotspot melalui PC maupun laptop pengguna.

5. Bimbingan Pengguna

Membantu pengguna yang belum familiar dengan fasilitas IT yang ada di perpustakaan.

6. E-journal

Perpustakaan melayani pengguna dalam penelusuran jurnal online pada tempat yang telah disediakan.

\section{Digital Library}

Perpustakaan melayani pengguna dalam mengakses koleksi digital (Laporan Akhir, Skripsi, Tesis).

8. Fotokopi

Layanan untuk membantu pengguna yang ingin memfotokopi sebagian isi koleksi.

\section{Sistem Layanan}

Sistem layanan di Perpustakaan Institut Pemerintah Dalam Negeri menggunakan sistem layanan terbuka, artinya pengguna bisa mengambil sendiri bahan-bahan yang diperlukan (buku, majalah, koran, jurnal, kamus). Sedangkan koleksi digital seperti CD/DVD dan Laporan Akhir/Skripsi/Tesis menggunakan sistem tertutup yang mana pengguna harus menghubungi petugas perpustakaan.

\section{Waktu Layanan}

Pelayanan perpustakaan diberlakukan sesuai hari dan jam kerja di Institut Pemerintah Dalam Negeri yaitu jam 08.00 sampai dengan 15.30 dan selanjutnya adanya tambahan operasional dimana pegawai bergiliran melakukan piket hingga malam hari sampai pukul 21.00 WIB untuk perpustakaan Institut Pemerintah Dalam Negeri di Jatinangor.

\section{METODE DAN PEMBAHASAN}

\section{Metode}

Metode Penelitian menurut Sugiyono (2014:2) adalah sebagai cara ilmiah untuk mendapatkan data dengan tujuan dan kegunaan tertentu". Metode yang digunakan dalam penelitian ini adalah deskriptif. Pengertian metode deskriptif menurut Sugiyono (2014:53) yaitu: "Suatu rumusan masalah yang berkenaan dengan pertanyaan terhadap keberadaan variabel mandiri, baik hanya pada satu variabel atau lebih.

Data yang akan diperlukan dalam melakukan proses penelitian ini adalah data primer dan sekunder. Dimana data primer langsung diambil oleh peneliti saat melakukan studi lapangan. Sedangkan, data sekunder diperoleh dengan cara membaca, mempelajari dan memahami melalui literatur, buku-buku, serta dokumen perpustakaan Institut Pemerintah Dalam Negeri Jatinangor. Sumber data dalam proses penelitian ini berasal dari informan dan literatur. Adapun pengumpulan data tersebut menggunakan teknik observasi dan studi pustaka. 
Kualitas pelayanan berhubungan erat dengan kepuasan pemustaka menerapkan indikator-indikator kualitas pelayanan yaitu Tangible, Reability, Responsiveness, Assurance dan Emphaty dipercaya perpustakaan mampu menumbuhkan kepuasan pemusataka. Model konsep penelitian kualitas pelayanan terhadap kepuasan pemustaka seperti pada gambar 1 di bawah ini:

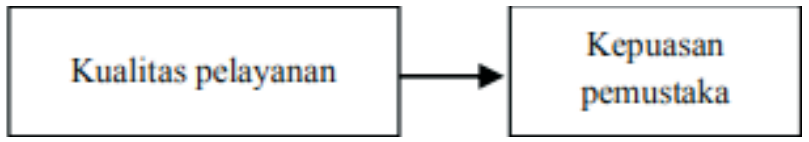

Gambar 3.1 Model Konsep

\section{Pembahasan}

Perpustakaan Institut Pemerintah Dalam Negeri sebagaimana perpustakaan di Perguruan Tinggi lain juga harus dapat berfungsi sebagai "Jantung Perguruan Tinggi". Untuk itu, perpustakaan harus selalu memberikan layanan yang kontributif terhadap aktivitas belajar mengajar, antara lain updating buku, jurnal, karya ilmiah, seri pengetahuan dalam bentuk DVD, e-book, novel serta koleksi dan penyediaan fasilitas lainnya. Diharapkan mahasiswa/praja Institut Pemerintah Dalam Negeri dapat menghabiskan sebagian waktunya untuk membaca buku, mengerjakan tugas sekaligus refreshing dengan memanfaatkan fasilitas yang ada.

Namun, dalam kenyataannya praja sebagai mahasiswa di lingkungan Institut Pemerintah Dalam Negeri Jatinangor banyak yang mengeluhkan bahwa kurangnya fasilitas komputer, komputer dengan bandwidth yang kecil dan kurangnya katalog penelusuran koleksi buku. Hal tersebut sangat berpengaruh terhadap kepuasan pemustaka yaitu praja dalam menggunakan layanan. Dimana pengertian kepuasan adalah perasaan senang atau kecewa seseorang yang muncul setelah membandingkan antara persepsi/kesannya terhadap kinerja (atau hasil) suatu produk dan harapan-harapannya (Asmuji, 2012).

Berdasarkan informasi tersebut penulis mencoba menganalisis mengenai idealnya perpustakaan dalam menjamin kepuasan praja di lingkungan Institut Pemerintah Dalam Negeri Jatinangor. Dalam hal ini khususnya pada penyediaan fasilitas penunjang layanan dan faktor lainnya di perpustakaan Institut Pemerintah Dalam Negeri Jatinangor. Dimensi kualitas layanan terdiri dari lima dimensi diantaranya adalah:

1. Tangible (Bukti fisik), yaitu berhubungan dengan fasilitas fisik, perlengkapan dan sarana dan prasarana yang disediakan serta komponen-kompenen utama kualitas pelayanan.

Berdasarkan hasil observasi dalam hal ini fasilitas fisik yang disediakan oleh perpustakaan Institut Pemerintah Dalam Negeri Jatinangor yaitu ruangan nyaman ber-AC, meja baca, hotspot gratis di semua lantai, penelusuran elektronik, LAN, loker penyimpanan tas dan sepatu, musola, dan toilet. Namun, dalam kenyataannya layanan berupa fasilitas dengan jumlah dan kualitas komputer yang disediakan tidak sesuai dengan yang diharapkan praja sebagai pustakawan. Komputer yang terbatas sedangkan jumlah praja yang aktif berkunjung ke perpustakaan Institut Pemerintah Dalam Negeri Jatinangor mencapai ratusan setiap harinya mengakibatkan terhambatnya kegiatan pemenuhan kebutuhan praja pada saat ini. Dimana praja harus bergantian menggunakan komputer untuk mencari informasi yang dibutuhkan. Bahkan pada saat melakukan pencarian ternyata praja pun masih mengeluhkan penggunaan internet dengan bandwidth yang kecil dalam proses pencariannya.

Internet merupakan salah satu alat untuk mencari informasi. Informasi yang tersedia di internet mencakup segala bidang baik pendidikan. Dalam hal ini perpustakaan tak bisa menghindari kehadiran internet ini, bahkan seharusnya internet dijadikan sebagai salah satu sarana akses informasi di perpustakaan, dengan demikian keduanya saling melengkapi. Sehingga fasilitas yang disediakan perpustakaan Institut Pemerintahan Dalam Negeri Jatinangor ini merupakan salah satu faktor yang sangat berpengaruh terhadap kepuasaan praja sebagai pemustaka. Dalam hal ini faktor utama kepuasan praja adalah fasilitas fisik yang dilengkapi dengan faktor layanan jasa yang diberikan pegawai perpustakaan itu sendiri dalam memenuhi kebutuhan praja di perpustakaan Institut Pemerintah Dalam Negeri Jatinangor.

Perlu diperhatikan idealnya jumlah komputer dan kapasitas internet agar tidak menjadi kendala bagi praja dalam memanfaatkan fasilitas perpustakaan. Melakukan penambahan komputer disesuaikan dengan jumlah keanggotaan aktif praja dapat dilakukan untuk memenuhi kepuasan praja sebagai pemustaka. Hal tersebut sejalan dengan penelitian yang dilakukan oleh Rusdin (2017) menyimpulkan bahwa maka dimensi tangible yang ada pada U Perpustakaan menunjukkan pengaruh signifikan terhadap kepuasan mahasiswa. 
2. Reability (keandalan), yaitu berkaitan suatu perusahaan mampu memberikan layanan secara akurat dan dapat dipercaya.

Keandalan dalam pelayanan perpustakaan berkaitan dengan keakuratan pencatatan dalam peminjaman, pelayanan yang cepat dan segera dari petugas, siap dalam melayani mahasiswa, kelancaran dalam melayani peminjaman dan pengembalian, keandalan layanan yang diberikan petugas perpustakaan. Hasil analisis yang dilakukan oleh Rusdin (2017) menyimpulkan bahwa dimensi reliability berpengaruh tidak signifikan terhadap kepuasan mahasiswa, hasil analisis dalam penelitiannya menunjukkan bahwa ternyata secara individu variabel Reliability berpengaruh sangat rendah terhadap kepuasan pemustaka. Sejalan dengan hasil wawancara dan observasi langsung ke lapangan, petugas Institut Pemerintah Dalam Negeri dapat melayani dengan baik praja sebagai pemustaka. Akan tetapi atas keterbatasan petugas dan fasilitas yang disediakan oleh perpustakaan Institut Pemerintah Dalam Negeri Jatinangor, mengakibatkan adanya beberapa pemustaka praja pada umumnya yang merasa kurang dilayani dengan baik. Pemustaka merasa sedikit kesulitan dalam mencari informasi yang mereka butuhkan sedangkan petugas hanya dapat melayani pemustaka secara bergantian. Pada saat kunjungan tidak terlalu banyak, petugas perpustakaan Institut Pemerintah Dalam Negeri Jatinangor dapat dengan baik melayani praja yang berkunjung. Akan tetapi, saat terjadi kepadatan pengunjung terlihat petugas merasa kewalahan dalam melayani pemustaka.

Secara garis besar petugas perpustakaan Institut Pemerintah Dalam Negeri Jatinangor dapat melayani praja dengan cukup baik. Kesulitan petugas dalam melayani terjadi saat kunjungan praja yang meningkat, hal tersebut dikarenakan kapasitas personel yang tidak sebanding dengan jumlah praja yang berkunjung ke perpustakaan Institut Pemerintah Dalam Negeri Jatinangor.

3. Responsivennes (daya tanggap), yaitu keinginan membantu dan merespon permintaan secara cepat dan tepat.

Daya tanggap dalam pelayanan di perpustakaan berkaitan dengan ketanggapan petugas dalam melayani, kesediaan petugas dalam membantu, prosedur layanan, ketanggapan petugas dalam mendengar keluhan dan saran, kesiapan merespon pertanyaan pengunjung. Berdasarkan hasil wawancara dan observasi lapangan, petugas perpustakaan Institut
Pemerintah Dalam Negeri Jatinangor sudah sangat memahami prosedur dalam jenis-jenis pelayanan yang disediakan. Baik dalam proses sirkulasi seperti peminjaman buku, perpanjangan peminjaman dan resiko yang dihadapi pada saat ada pemustaka yang menyalahi prosedur. Dalam hal keanggotaan, petugas sangat memahami proses pendaftaran dan perpanjangan keanggotaan perpustakaan. Petugas pun membantu penggunaan fasilitas yang disediakan oleh perpustakaan Institut Pemerintah Dalam Negeri Jatinangor seperti multimedia, internet, e-journal, digital library dan foto kopi. Penelitian yang dilakukan oleh Rusdin (2017) menyimpulkan bahwa maka dimensi responsivennes yang ada pada Perpustakaan menunjukkan pengaruh signifikan terhadap kepuasan mahasiswa dengan kategori sedang. Dimana berdasarkan hasil observasi langsung memang daya tanggap petugas perpustakaan Institut Pemerintah Dalam Negeri Jatinangor terhadap kepuasan pemustaka yaitu praja.

Akan tetapi yang dikeluhkan pemustaka adalah lambatnya internet yang digunakan dalam komputer di perpustakaan sehingga petugas yang melayani tidak dapat membantu dikarenakan untuk masalah teknis ini harus diperbaiki oleh ahlinya yaitu pihak IT perpustakaan Institut Pemerintah Dalam Negeri Jatinangor.

4. Assurance (Jaminan), yaitu meliputi kesopanan karyawan, keamanan dan pengetahuan karyawan.

Jaminan dalam melakukan pelayanan berkaitan dengan sopan santun petugas kepada pemustaka, jaminan akan keamanan pada pemustaka, pengetahuan yang dimiliki petugas, dan kejujuran petugas. Berdasarkan hasil observasi petugas selalu mendapatkan pelatihan dalam menunjang kualitas pelayanan terhadap praja pada umumnya. Sehingga praja sebagai pemustaka dapat dilayani dan mendapatkan edukasi mengenai koleksi buku yang disediakan oleh petugas. Hal tersebut membuat praja mendapatkan informasi sebagai bahan referens belajar yang dibutuhkan. Hal tersebut selaras dengan hasil penelitian oleh Rusdin (2017), dimana menyimpulkan bahwa dimensi jaminan berpengaruh terhadap kepuasan pemustaka. Ini menunjukkan bahwa pemustaka yang berkunjung mengutamakan perasaan aman dan nyaman ketika berada dalam ruang perpustakaan.

Selain itu, petugas perpustakaan Institut Pemerintah Dalam Negeri pun menyediakan tempat penitipan atau penyimpanan barang anggota perpustakaan. Hal tersebut dilakukan untuk menjamin kenyaman 
pemustaka dan mempermudah pemustaka yaitu praja dalam memanfaatkan fasilitas dan layanan perpustakaan. Petugas menjamin keamanan bagi anggota untuk menitipkan barangnya dengan melakukan prosedur yang telah disediakan. Akan tetapi, tak hanya membutuhkan kualitas layanan tersebut, keterbatasan fasilitas yaitu kotak penyimpanan yang tidak sebanding dengan jumlah kunjungan pemustaka membuat petugas merasa khawatir akan keamanan barang yang dititipkan begitu pun sebaliknya pemustaka pun merasa kurang nyaman dengan barang yang dititipkannya.

5. Emphaty (empati), yaitu berhubungan dengan karyawan mampu memahami permasalahan pelanggan dan mengatasi keluhan.

Pemustaka akan merasakan nyaman untuk memanfaatkan layanan yang ditawarkan perpustakaan apabila ada jaminan kemampuan, kesopanan, dan sifat dapat dipercaya dari petugas perpustakaan. Kepedulian petugas terhadap masalah pengunjung, kemudahan pemustaka dalam menemui petugas, dukungan manajemen perpustakaan terhadap kepentingan pemustaka. Hasil penelitian oleh Rusdin (2017), menunjukkan bahwa ternyata secara individu dimensi empathy berpengaruh terhadap kepuasan pemustaka yang menggunakan perpustakaan. Hal ini sejalan dengan hasil observasi penulis dimana adanya pemustaka yang merasa kurang puas dengan sikap petugas perpustakaan yang terkadang sulit ditemui untuk dimintai informasi. Bukan dikarenakan adanya oknum di lingkungan perpustakaan Institut Pemerintah Dalam Negeri Jatinangor. Akan tetapi, dikarenakan kurangnya personel petugas dalam melayani pemustaka pada saat terjadinya kepadatan pengunjung. Petugas tidak dapat melayani beberapa pemustaka dalam satu waktu dengan permintaan yang berbeda. Hal ini dibutuhkan pemanfaatan fasilitas yang sebetulnya dapat mempermudah pemustaka untuk mencari buku, jurnal maupun informasi lainnya secara mandiri.

Dapat terlihat dari kelima dimensi kualitas pelayanan yang diterapkan di perpustakaan Institut Pemerintah Dalam Negeri. Dimensi bukti fisik yaitu fasilitas komputer, internet dan penelusuran katalog merupakan faktor yang paling berpengaruh terhadap kepuasan pelanggan. Sedangkan, keempat dimensi seperti: keandalan, daya tanggap, jaminan, dan empati merupakan faktor yang cukup berpengaruh atas kepuasan yang dirasakan pemustaka yaitu praja pada umumnya.

\section{KESIMPULAN DAN SARAN}

\section{Kesimpulan}

Berdasarkan hasil analisis dalam pembahasan, penulis menyimpulkan kelima dimensi kualitas layanan (tangible atau bukti fisik, reability atau keandalan, responsiveness atau daya tanggap, assurance atau jaminan, dan empathy atau empati) berpengaruh terhadap kepuasan praja sebagai pemustaka perpustakaan Institut Pemerintah Dalam Negeri di Jatinangor. Dimana yang sangat berpengaruh adalah fasilitas yang disediakan perpustakaan sedangkan pelayanan petugas secara masing-masing individu merupakan faktor pendukung dalam jalannya administrasi perpustakaan Institut Pemerintah Dalam Negeri di Jatinangor. Selaras dengan hasil analisis oleh Rusdi (2017) yang dalam penelitiannya menyimpulkan bahwa kualitas pelayanan perpustakaan berpengaruh terhadap kepuasan pemustaka.

\section{Saran}

Berdasarkan kesimpulan hasil analisis, penulis menyarankan baik bagi pustakawan, petugas, pengelola dan pengurus perpustakaan Institut Pemerintah Dalam Negeri di Jatinangor untuk menyesuaikan penambahan fasilitas komputer beserta internet sebagai pendukung kenyamanan praja dalam pemanfaatan perpustakaan. Dan mempertimbangkan lagi penyediaan fasilitas yang ideal bagi penyelenggaraan sirkulasi pelayanan perpustakaan. Evaluasi kembali apakah dibutuhkan penambahan personel ataupun dibutuhkan pelatihan bagi petugas dalam melayani pemustaka. Dan bagi pustakawan dibutuhkan ide dan masukan mengenai penambahan katalog buku yang disediakan perpustakaan agar lebih lengkap dan menarik bagi praja ataupun pemustaka lainnya.

\section{DAFTAR PUSTAKA}

A. Parasuraman, Valarie A. Zeithaml, and Leonard L. Berry. 1988. "SERVQUAL: A Multiple Item Scale for Measuring Consumer Perceptions of Service Quality". Journal of Retailing. Volume 64 Number 1 Spring 1988. Cambridge, MA: Marketing Science Institute.

Deviana Fadhlya, Yogi Suprayogi, Imanudin. 2017. “Kualitas Pelayanan Perpustakaan Di Badan Perpustakaan Dan kearsipan Daerah Provinsi Jawa Barat." Jurnal Administrasi Negara Volume 2. No 1, Agustus 2017. Bandung: Universitas Padjadjaran.

Hasugian Jonner. 2009. Dasar-Dasar Ilmu Perpustakaan dan Informasi. Medan: USU Press. 
https://gtcistudy.com/

https://sites.google.com/a/ipdn.ac.id/perpustakaan-ipdn/ home/prakata/profil

Kotler, Philip dan Gary Armstrong. 2012. Prinsip - Prinsip Pemasaran. Jakarta: Erlangga.

Lupiyuadi dan Hamdani. 2006. Manajemen Pemasaran Jasa. Jakarta: Penerbit Salemba Empat.

Rusdin. 2017. "Pengaruh Kualitas Pelayanan Terhadap Tingkat Kepuasan Pemustaka Di Upt Perpustakaan Universitas Tadulako". Jurnal Katalogis, Volume 5 Nomor 11, November 2017 hlm 65-77. Palu: Universitas Tadulako.
Standar Nasional Perpustakaan Tahun 2011, Perpustakaan Nasional Republik Indonesia.

Sulistyo Basuki. 2004. Pengantar Ilmu Perpustakaan. Jakarta: Gramedia Pustaka Utama. Sulistyo Basuki. 1992. Pengantar Ilmu Perpustakaan. Jakarta: Gramedia Pustaka Utama.

Tjiptono. 2001. Manajemen Pemasaran dan Analisa Perilaku Konsumen. Yogyakarta: BPFE.

Undang-Undang Republik Indonesia No. 43 Tahun 2007 Tentang Perpustakaan 